УДК 664.69

\title{
RESEARCH OF FOOD, BIOLOGICAL VALUE AND DIGESTIBILITY OF GLUTEN-FREE PASTA MADE FROM CORN FLOUR
}

\author{
O. Rozhno, V. Yurchak, V. Rak \\ National University of Food Technologies
}

\begin{tabular}{|c|c|}
\hline Key words: & ABSTRACT \\
\hline $\begin{array}{l}\text { Gluten-free pasta } \\
\text { Chemical composition } \\
\text { Food energy } \\
\text { Biological value } \\
\text { Digestibility }\end{array}$ & $\begin{array}{l}\text { This study identifies the nutritional, biological value and } \\
\text { digestibility for different recipes of gluten-free pasta made } \\
\text { from corn flour. It is established that these products contain } \\
\text { more vitamins, especially } \beta \text {-carotene, vitamins } B-B_{1}, B_{2} \text {, } \\
\text { PP and minerals: iron, calcium, phosphorus, magnesium, }\end{array}$ \\
\hline $\begin{array}{l}\quad \text { Article history: } \\
\text { Received } 13.11 .2017 \\
\text { Received in revised form } \\
11.12 .2017 \\
\text { Accepted } 27.12 .2017\end{array}$ & $\begin{array}{l}\text { compared with wheat products. Using dry egg protein in the } \\
\text { amount of } 5.0 \% \text { contributes to the enrichment of pasta } \\
\text { products with protein which contains } 10.94 \mathrm{mg} \text { per } 100 \mathrm{~g} \text {. It } \\
\text { was found that digestion of pasta products from corn is not } \\
\text { significantly different from pasta from wheat flour. The }\end{array}$ \\
\hline $\begin{array}{l}\text { Corresponding author: } \\
\text { O. Rozhno } \\
\text { E-mail: } \\
\text { npnuht@ukr.net }\end{array}$ & $\begin{array}{l}\text { digestibility of protein substances is higher for developed } \\
\text { gluten-free pasta. }\end{array}$ \\
\hline
\end{tabular}

DOI: $10.24263 / 2225-2924-2017-23-6-20$

\section{ДОСЛІДЖЕННЯ ХАРЧОВОЇ, БІОЛОГІЧНОЇ ЦІННОСТІ ТА ПЕРЕТРАВЛЮВАНОСТІ БЕЗГЛЮТЕНОВИХ МАКАРОННИХ ВИРОБІВ 3 КУКУРУДЗЯНОГО БОРОШНА}

\author{
О.В. Рожно, В.Г. Юрчак, В.П. Рак \\ Національний університет харчових технологій
}

У статті визначено харчову, біологічну иінність і перетравлюваність для розроблених за різними рецептурами безглютенових макаронних виробів 3 кукурудзяного борошна. Встановлено, що в иии виробах міститься більше вітамінів; особливо $\beta$-каротину, вітамінів групи $B-B_{1}, B_{2}, P P$ і мінеральних речовин (заліза, кальчію, фосфору, магнію), порівняно з пшеничними виробами. Використання СЯБ у кількості 5,0\% сприяе збагаченню макаронних виробів білком, вміст якого сягає 10,94 мг на 100 г. Визначено, що перетравлюваність макаронних виробів з кукурудзяного і пшеничного борошна суттєво не відрізняється. Перетравлюваність білкових речовин є вищою для розроблених безглютенових макаронних виробів.

Ключові слова: безглютенові макаронні вироби, хімічний склад, енергетична цінність, біологічна цінність, перетравлюваність. 
Постановка проблеми. Останнім часом фахівці харчової промисловості значну увагу приділяють розробленню продуктів дієтичного, оздоровчого та профілактичного призначення і технології їх виготовлення. Створення таких продуктів передбачає збагачення їх певними харчовими інгредієнтами чи, навпаки, повне їх виключення [1]. Так, у разі розроблення дієтичних виробів для хворих на целіакію необхідно виключити білок глютен, а для хворих на фенілкетонурію - взагалі виключити білок. У першому випадку застосовують сировину, що не містить глютену. У разі розроблення безбілкових виробів (хліба, макаронних виробів, печива) основною сировиною $є$ крохмаль [2].

Розробники таких виробів приділяють особливу увагу забезпеченню їх структури, прийнятних смакових властивостей тощо. Проте важливе значення має надання цим виробам належної харчової та біологічної цінності.

Використання кукурудзи, рису, гречки як сировини 3 виробництва продуктів для дотримання безглютенової дієти описано в [3; 4].

Кукурудзяне борошно має певні переваги для виготовлення безглютенових макаронних виробів 3 нього. 3 огляду на хімічний склад воно характеризується як таке, що не містить глютену. Недоліком є низький вміст білків. Проте кукурудзяне борошно має цінний хімічний склад за вмістом вітамінів $\mathrm{B}_{1}, \mathrm{~B}_{2}$, РP та $\beta$-каротину, а також мінеральних речовин: кальцію, магнію, заліза, фосфору [5].

Нами розроблені макаронні вироби з кукурудзяного борошна тонкого помелу з використанням структуроутворювачів — камеді ксантану та карбоксиметилцелюлози (КМЦ) [6; 7]. Також використовували білкові продукти: желатин і сухий яєчний білок (СЯБ), які вносили для збагачення макаронних виробів білком і для поліпшення структури виробів [8; 9]. Розроблені рецептури безглютенових макаронних виробів без використання добавок структуроутворювачів - 3 внесенням екструдованого кукурудзяного борошна або заварюванням частини кукурудзяного борошна тонкого помелу [9; 10]. Встановлено дозування структуроутворювачів, кількість внесеного екструдованого або завареного борошна, які забезпечують найкращу якість виробів за показниками міцності, варильних властивостей, зокрема переходу сухих речовин у варильну воду.

Оскільки добовий раціон харчування для людей хворих на целіакію дуже обмежений, він корегується залежно від харчової та біологічної цінності безглютенових харчових продуктів. Зважаючи на це, важливим є дослідження хімічного складу, енергетичної цінності та амінокислотного скору для розроблених безглютенових макаронних виробів з кукурудзяного борошна. Для корегування добового раціону харчування для хворих на целіакію також необхідно враховувати покриття добової потреби (інтегральний скор) у поживних речовинах при вживанні даних макаронних виробів.

Білки та вуглеводи кукурудзяного борошна за хімічним складом відрізняються від білків пшеничного борошна, а швидкість перетравлювання $\mathrm{\epsilon}$ одним із факторів, що визначають фізіологічну цінність виробів, виготовлених з нього. Отже, важливо вивчити перетравлюваність макаронних виробів 3 кукурудзяного борошна, виготовлених за різними рецептурами. 
Матеріали і методи. Для визначення хімічного складу безглютенових макаронних виробів 3 кукурудзяного борошна розраховували вміст білків, жирів, вуглеводів, харчових волокон, мінеральних речовин і вітамінів, виходячи з хімічного складу борошна та інших видів сировини.

Для того, щоб визначити кількість борошна в 100 г продукту, розраховували

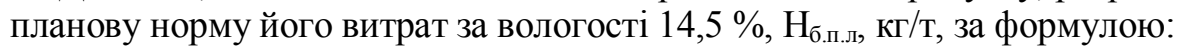

$$
\mathrm{H}_{\text {б.п.л. }}=3_{\mathrm{T}}+\mathrm{B}_{\mathrm{B}}+\mathrm{H}_{\mathrm{B}} \text {, }
$$

де $3_{\mathrm{T}}$ - технологічні затрати борошна, кг/т; $\mathrm{B}_{\mathrm{B}}$ - питома величина врахованих втрат борошна, кг/т; $\mathrm{H}_{\mathrm{B}}$ - питома величина незворотніх втрат борошна, кг/т.

Технологічні затрати, $3_{\text {, }}$ кг/т, розраховуються за формулою:

$$
3_{\text {т }}=\frac{100-W_{\text {вир }}}{100-W_{\text {бор }}} \cdot 1000,
$$

де $W_{\text {вир }}, W_{\text {бор }}$ - вологість виробів і борошно відповідно, \%;

Норму витрат борошна для виробів зі структуроутворювачами, $\mathrm{H}_{\text {б.п.л }}$, кг/т, розраховували за формулою:

$$
\mathrm{H}_{\text {б.п.л }}=\frac{\mathrm{H}_{\text {б.п.л }} \cdot\left(100-W_{\sigma}\right)}{\left(100-W_{6}\right)+a},
$$

де $a-$ поправочний коефіцієнт на додаткову сировину, в даному випадку на структуроутворювачі для виготовлення макаронних виробів.

Поправочний коефіцієнт розраховували за формулою:

$$
a_{i}=0,001 \cdot \mathrm{P}_{\text {н.д. }}^{i}\left(100-W_{\text {пл.д. }}^{i}\right),
$$

де $\mathrm{P}_{\text {н.д. }}^{i}$ - норми добавок на 1 т борошна за рецептурою.

Норма витрат додадкової сировини, $\mathrm{H}_{\text {Д.пл }}$, кг/т, для кожного виду виробів визначається за формулою:

$$
\mathrm{H}_{\text {Д.пл }}=0,001 \cdot \mathrm{P}_{\text {н.Д }} \cdot \mathrm{H}_{\text {бпл }}^{\text {д }},
$$

де $\mathrm{H}_{\text {б.лл }}^{\text {д }}$ - планова норма витрат борошна на 1 т виробів, кг/т; $\mathrm{P}_{\text {н.д }}-$ норма добавок на 1 т борошна за рецептурою, кг.

Кількість білків у виробах, $G_{\sigma^{\prime}}, \Gamma / 100$ г, розраховували за формулою:

$$
G_{\sigma^{\prime}}=\frac{\Sigma G_{\tilde{6}}^{i} \cdot G_{i}}{100},
$$

де $G_{\sigma}^{i}$ - вміст білків, г у 100 г кожного виду сировини (за нормативними документами на сировину або згідно з таблицями хімічного складу сировини); $G_{i}$ - витрати кожного ( $i$-того) виду сировини, г, для виготовлення 100 г макаронних виробів.

Кількість жирів, вуглеводів, харчових волокон, вітамінів і мінеральних речовин розраховували за аналогічними формулами. 
Енергетичну цінність 100 г виробів, ЕЦ ${ }^{100}$, ккал, розраховували за формулою:

$$
\mathrm{E}^{100}=G_{\tilde{\sigma}}^{100} \cdot 4,0+G_{\text {ж}}^{100} \cdot 9,0+G_{\mathrm{B}}^{100} \cdot 4,0,
$$

де $G_{\tilde{\sigma}}^{100}, G_{ж}^{100}, G_{\mathrm{B}}^{100}$ - загальна кількість білків, жирів та вуглеводів в 100 г виробу, г.

Розрахунок інтегрального скору для макаронних виробів здійснювали для 100 г продукту. Для цього визначали, на скільки покривається добова норма споживання основних нутрієнтів у разі вживання 100 г макаронних виробів.

Інтегральний скор для білка, $I_{\mathrm{H}}^{\sigma}, \%$, визначають за такою формулою:

$$
I_{\mathrm{н}}^{\text {б }}=\frac{G_{\text {б }}^{\prime}}{G_{\text {б.доб }}},
$$

де $G_{\text {б }}^{\prime}$ - кількість білків у 100 г харчового продукту, г; $G_{\text {б.доб }}-$ добова потреба у білках для відповідної категорії населення. Середню добову потребу дорослої людини в харчових інгредієнтах та енергії приймали для чоловіків віком від 18-29 років, І групи інтенсивності праці.

За аналогічними формулами визначали інтегральний скор для інших нутрієнтів: жирів, вуглеводів, харчовин волокон, вітамінів і мінеральних речовин.

Біологічну цінність розроблених макаронних виробів оцінювали за амінокислотним скором.

Амінокислотний скор, АК скор, \%, для кожної з незамінних амінокислот розраховували за формулою:

$$
\text { АК скор }=\frac{\text { мг АК в1 г досліджуваного білка }}{\text { мГ АК в1 г«еталонного білка» }} \cdot 100,
$$

де АК - будь-яка незамінна амінокислота. Дані щодо вмісту кожної амінокислоти в еталонному білку брали з положень ФАО/ВООЗ (1973).

Перетравлюваність вуглеводів визначали для всіх зразків макаронних виробів з кукурудзяного борошна зі застосуванням ферменту «Панзинорм» за кількістю редукуючих речовин $(\mathrm{X}), \%$ на СР. Кількість продуктів гідролізу визначали йодометричним методом Шорля у модифікації ВНДІХП [11].

Перетравлюваність білків у макаронних виробах визначали за швидкістю ïx гідролізу ферментами пепсин-трипсин in Vitro за методом ПокровськогоЄртанова [12] у зразках з кукурудзяного борошна, частина якого заварювалась, та $з$ желатином і СЯБ.

За контроль приймали перетравлюваність макаронних виробів із пшеничного борошна.

Результати і обговорення. Визначені хімічний склад та енергетична цінність безглютенових макаронних виробів 3 пшеничного і кукурудзяного борошна наведені в табл. 1.

3 літературних джерел відомо [5], що у хімічному складі кукурудзяного борошна не міститься клейковинного білка. Як підтверджують дані, наведені в табл. 1, безглютенові макаронні вироби з кукурудзяного борошна збіднені на білок, і його кількість становить близько 7,5 г на 100 г продукту, що на 3,7 г 
менше, ніж у пшеничних макаронних виробах. Внесення сухого яєчного білка (СЯБ) у кількості 5,0\% дає змогу збільшити вміст білка у макаронних виробах до рівня пшеничних макаронних виробів - 10,94 г на 100 г продукту. Внесення желатину як структуроутворювача у кількості $1,0 \%$ підвищує вміст білка приблизно на 0,8 г на 100 г продукту.

Кількість жирів у всіх зразках безглютенових макаронних виробів з кукурудзяного борошна дещо більша, ніж у пшеничних виробах, і становить $1,51-1,54$ г на 100 г продукту. Це $\epsilon$ одним із чинників, що збільшує їх енергетичну цінність.

Кількість вуглеводів у всіх зразках макаронних виробів з кукурудзяного борошна знаходиться в межах 69,63-73,36 г на 100 г продукту.

Найменшу кількість вуглеводів містить зразок макаронних виробів з СЯБ 69,63 г на 100 г продукту. Макаронні вироби з кукурудзяного борошна мають більший вміст вуглеводів, в тому числі харчових волокон 4,25-4,48 г на 100 г продукту, порівняно з пшеничними.

У всіх зразках безглютенових макаронних виробів кількість вітамінів майже однакова. Макаронні вироби з кукурудзяного борошна, порівняно 3 пшеничними виробами, містять значно більшу кількість вітамінів групи В: $\mathrm{B}_{1}$ (приблизно у 2 рази), $\mathrm{B}_{2}$ та PР (у 1,5 раза). Проте вміст токоферолу в них нижчий і становить приблизно 0,60 мг на 100 г виробів, порівняно з 1,50 мг на 100 г пшеничних виробів.

У безглютенових макаронних виробах $\beta$-каротин значною мірою впливає на їхнє забарвлення і його кількість знаходиться в межах $0,105-0,111$ мг на 100 г продукту. У пшеничних макаронних виробах 3 хлібопекарського борошна не міститься $\beta$-каротину.

У всіх зразках макаронних виробів з кукурудзяного борошна міститься майже у 2 рази більше магнію, приблизно на 26\% більше фосфору, на $61 \%$ більше заліза та трохи більше кальцію, порівняно з пшеничними виробами.

Таблиия 1. Хімічний склад та енергетична цінність безглютенових макаронних виробів 3 кукурудзяного борошна

\begin{tabular}{|c|c|c|c|c|c|}
\hline \multirow{3}{*}{$\begin{array}{c}\text { Хімічний } \\
\text { склад в } 100 \text { г } \\
\text { продукту }\end{array}$} & \multirow{3}{*}{\begin{tabular}{|c|} 
Макаронні \\
вироби з \\
пшеничного \\
хлібопекарського \\
борошна вищого \\
сорту \\
(контроль)
\end{tabular}} & \multicolumn{4}{|c|}{ Макаронні вироби з кукурудзяного борошна } \\
\hline & & \multicolumn{3}{|c|}{$\begin{array}{c}\text { 3 використанням } \\
\text { структуроутворювачів у } \\
\text { кількості, \% до маси борошна }\end{array}$} & \multirow{2}{*}{$\begin{array}{c}\text { без застосування } \\
\text { структуроутворювачів, } \\
\text { з використанням } \\
\text { екструдованого } \\
\text { кукурудзяного борошна } \\
(20 \%) \text { або частини } \\
\text { завареного } \\
\text { кукурудзяного борошна } \\
\text { тонкого помелу }(10 \%)\end{array}$} \\
\hline & & $\begin{array}{c}\text { ксантану, } 0,7 \\
\text { або } \\
\text { КМЦ, 0,3 }\end{array}$ & $\begin{array}{c}\text { желатину, } \\
1,0\end{array}$ & $\begin{array}{c}\text { СЯБ, } \\
5,0\end{array}$ & \\
\hline 1 & 2 & 3 & 4 & 5 & 6 \\
\hline Білки, г & 11,0 & $7,27-7,30$ & 8,13 & 10,94 & 7,33 \\
\hline Жири, г & 1,34 & 1,52 & 1,51 & 1,54 & 1,53 \\
\hline Вуглеводи, г & 70,50 & $73,06-72,92$ & 72,60 & 69,63 & 73,36 \\
\hline $\begin{array}{c}\text { в т. ч. харчові } \\
\text { волокна, г }\end{array}$ & 3,72 & 4,44 & 4,43 & 4,25 & 4,48 \\
\hline
\end{tabular}


Продовження табл. 1.

\begin{tabular}{|c|c|c|c|c|c|}
\hline 1 & 2 & 3 & 4 & 5 & 6 \\
\hline $\begin{array}{c}\text { Вітаміни: Е } \\
\text { (токоферол), мг }\end{array}$ & 1,50 & 0,61 & 0,60 & 0,58 & 0,61 \\
\hline В-каротин, мг & 0 & 0,105 & 0,108 & 0,111 & 0,108 \\
\hline В1 (тіамін), мг & 0,17 & 0,36 & 0,35 & 0,34 & 0,35 \\
\hline $\begin{array}{c}\text { В2 (рибофла- } \\
\text { він), мг }\end{array}$ & 0,04 & 0,13 & 0,15 & 0,13 & 0,13 \\
\hline РP (ніацин), мг & 1,20 & 1,83 & 1,83 & 1,74 & $1,80-1,83$ \\
\hline $\begin{array}{c}\text { Макро- та } \\
\text { мікроелементи: } \\
\text { Са (кальцій), мг }\end{array}$ & 18,91 & 20,0 & 20,89 & 53,15 & 20,0 \\
\hline Fе (залізо), мг & 1,66 & 2,74 & 2,71 & 2,74 & 2,7 \\
\hline Р (фосфор), мг & 87,0 & $110,10-110,55$ & 111,70 & 119,82 & 109,0 \\
\hline Мg (магній), мг & 16,0 & $30,30-30,43$ & 30,50 & 32,85 & 30,0 \\
\hline $\begin{array}{c}\text { Енергетична } \\
\text { цінність, ккал }\end{array}$ & 338 & 343 & \multicolumn{2}{|c|}{343} & 343 \\
\hline
\end{tabular}

Макаронні вироби із СЯБ, порівняно з іншими зразками кукурудзяних макаронних виробів, за вмістом макро- і мікроелементів $€$ найбільш багатими на кальцій - 53,15 мг на 100 г продукту, фосфор - 119,82 мг на 100 г продукту та магній - 32,85 мг на 100 г продукту.

Енергетична цінність усіх зразків макаронних виробів 3 кукурудзяного борошна однакова і становить 343 ккал.

Отримані значення забезпечення добової потреби (інтегральний скор) в основних нутрієнтах (\%) при вживанні 100 г макаронних виробів 3 кукурудзяного борошна наведені в табл. 2. Як видно з табл. 2, безглютенові макаронні вироби з кукурудзяного борошна покривають добову потребу в білках на $10,79-16,33 \%$. Зразок з внесеним СЯБ найбільше покриває добову норму білка - на $16,33 \%$, серед макаронних виробів з кукурудзяного борошна та має практично однаковий інтегральний скор по білку порівняно з пшеничними $16,42 \%$.

Інтегральний скор по вуглеводах для всіх зразків макаронних виробів, крім пшеничних макаронних виробів та виробів із СЯБ, знаходиться в межах $18,7 \%$. Покриття добової потреби в вуглеводах для виробів з СЯБ $є$ дещо меншим і становить 17,79\%. Для безглютенових макаронних виробів покриття добової норми споживання вітамінів вище, порівняно з пшеничними виробами, а саме: вітаміну В1 - в 2 рази; B 2 - в 3,4 раза та $\mathrm{PP}$ - в 1,5 раза.

Кукурудзяне борошно багате залізом, кальцієм, фосфором. Інтегральний скор за мінеральними речовинами для всіх зразків безглютенових макаронних виробів $\epsilon$ вищим, порівняно з пшеничними виробами, і складає: для заліза - 18,04\%, для фосфору - 9,17-9,99 \%, для магнію - 7,88-8,21\%. Макаронні вироби з СЯБ найбільше задовольняють потребу в мінеральних речовинах, порівняно з іншими зразками, зокрема за кальцієм - на 4,43\%.

Значення амінокислотного скору для безглютенових макаронних виробів наведені в табл. 3 . 


\section{Таблиия 2. Забезпечення добової потреби в основних нутріснтах}

\begin{tabular}{|c|c|c|c|c|c|c|}
\hline \multirow[b]{4}{*}{$\begin{array}{l}\text { Хімічний } \\
\text { склад }\end{array}$} & \multirow{4}{*}{$\mid \begin{array}{c}\text { Середня } \\
\text { добова } \\
\text { потреба в } \\
\text { основних } \\
\text { нутрі- } \\
\text { єнтах }\end{array}$} & \multicolumn{5}{|c|}{ Інтегральний скор, \% при вживанні 100 г макаронних виробів } \\
\hline & & \multirow{3}{*}{$\begin{array}{c}3 \\
\text { пшеничного } \\
\text { хлібопекар- } \\
\text { ського } \\
\text { борошна } \\
\text { вищого } \\
\text { сорту }\end{array}$} & \multicolumn{4}{|c|}{ з кукурудзяного борошна } \\
\hline & & & \multicolumn{3}{|c|}{$\begin{array}{c}\text { 3 використанням як } \\
\text { структуроутворювачів у } \\
\text { кількості, \% до маси борошна }\end{array}$} & \multirow{2}{*}{$\begin{array}{c}\text { без застосування } \\
\text { структуроутворю- } \\
\text { вачів, } \\
\text { з використанням } \\
\text { екструдованого } \\
\text { кукурудзяного } \\
\text { борошна }(20 \%) \text { або } \\
\text { частини }(10 \%) \\
\text { завареного } \\
\text { кукурудзяного } \\
\text { борошна тонкого } \\
\text { помелу }\end{array}$} \\
\hline & & & $\begin{array}{c}\text { ксантану, 0,7 } \\
\text { або } \\
\text { КМЦ, 0,3 }\end{array}$ & $\mid \begin{array}{c}\text { желатину, } \\
1,0\end{array}$ & $\mid \begin{array}{c}\text { СЯБ, } \\
5,0\end{array}$ & \\
\hline Білки, г & 67 & 16,42 & $10,79-10,90$ & 12,13 & 16,33 & 10,93 \\
\hline Жири, г & 68 & 1,97 & 2,24 & 2,23 & 2,26 & 2,24 \\
\hline Вуглеводи, г & 392 & 17,98 & $18,64-18,60$ & 18,52 & 17,79 & 18,71 \\
\hline $\begin{array}{c}\text { в т. ч. харчові } \\
\text { волокна, г }\end{array}$ & 25 & 14,88 & 17,76 & 17,72 & 17,00 & 17,92 \\
\hline $\begin{array}{c}\text { Вітаміни: } \\
\text { Е (токоферол), } \\
\text { мГ }\end{array}$ & 15 & 10,00 & 4,06 & 4,03 & 3,87 & 4,07 \\
\hline B1 (тіамін), мг & 1,6 & 10,63 & 22,19 & 22,03 & 21,14 & 22,50 \\
\hline $\begin{array}{c}\text { В2 } \\
\text { (рибофлавін), } \\
\text { мГ } \\
\end{array}$ & 2 & 2,00 & 6,59 & 7,55 & 6,28 & 6,61 \\
\hline РP (ніацин), мг & 22 & 5,45 & 8,30 & 8,31 & 7,91 & $8,18-8,32$ \\
\hline $\begin{array}{l}\text { Макро- та } \\
\text { мікроеле- } \\
\text { менти: Са } \\
\text { (кальцій), мг }\end{array}$ & 1200 & 1,58 & 1,70 & 1,74 & 4,43 & 1,70 \\
\hline $\mathrm{Fe}$ (залізо), мг & 15 & 11,07 & 18,26 & 18,24 & 18,04 & 18,3 \\
\hline $\mathrm{P}$ (фосфор), мг & 1200 & 7,25 & $9,17-9,21$ & 9,31 & 9,99 & 9,24 \\
\hline Mg (магній), мг & 400 & 4,00 & $7,58-7,61$ & 7,62 & 8,21 & 7,6 \\
\hline
\end{tabular}

Таблиия 3. Амінокислотний скор (АК скор) безглютенових макаронних виробів з кукурудзяного борошна

\begin{tabular}{|c|c|c|c|c|c|c|c|c|c|}
\hline \multirow{4}{*}{$\begin{array}{l}\text { Незамінні } \\
\text { амінокис- } \\
\text { лоти }\end{array}$} & \multirow{4}{*}{$\begin{array}{c}\text { Еталонний } \\
\text { білок (за } \\
\text { ФАО/ВООЗ) } \\
\text { мг/г білка }\end{array}$} & \multicolumn{8}{|c|}{ Макаронні вироби } \\
\hline & & \multirow{2}{*}{\multicolumn{2}{|c|}{$\begin{array}{c}3 \text { пшеничного } \\
\text { хлібопекар- } \\
\text { ського } \\
\text { борошна } \\
\text { вищого сорту } \\
\text { (контроль) }\end{array}$}} & \multirow{2}{*}{\multicolumn{2}{|c|}{$\begin{array}{c}3 \text { кукурудзяного } \\
\text { борошна } \\
\text { без застосування } \\
\text { добавок } \\
\text { структуроутво- } \\
\text { рювачів }\end{array}$}} & \multicolumn{4}{|c|}{$\begin{array}{c}\text { з кукурудзяного борошна } \\
\text { з внесенням у кількості, } \\
\text { до маси борошна }\end{array}$} \\
\hline & & & & & & \multicolumn{2}{|c|}{ желатину, 1,0% } & \multicolumn{2}{|c|}{ СЯБ, 5,0 \% } \\
\hline & & $\begin{array}{c}\text { мг/г } \\
\text { білка }\end{array}$ & $\begin{array}{c}\text { АК } \\
\text { скор, } \\
\%\end{array}$ & $\begin{array}{c}\text { мг/г } \\
\text { білка }\end{array}$ & $\begin{array}{c}\text { АК } \\
\text { скор, \% }\end{array}$ & $\begin{array}{c}\text { мг/г } \\
\text { білка }\end{array}$ & $\begin{array}{c}\text { АК } \\
\text { скор, \% }\end{array}$ & $\begin{array}{c}\text { мг/г } \\
\text { білка }\end{array}$ & $\begin{array}{c}\text { АК } \\
\text { скор, \% }\end{array}$ \\
\hline 1 & 2 & 3 & 4 & 5 & 6 & 7 & 8 & 9 & 10 \\
\hline Валін & 50 & 46 & 91,5 & 57 & 115,5 & 58 & 115,9 & 64 & 121,9 \\
\hline золейцин & 40 & 42 & 104,4 & 43 & 108,3 & 44 & 108,5 & 50 & 115,4 \\
\hline
\end{tabular}




\begin{tabular}{|c|c|c|c|c|c|c|c|c|c|}
\hline \multicolumn{10}{c}{ Продовження табл. 3. } \\
\hline 1 & 2 & 3 & 4 & 5 & 6 & 7 & 8 & 9 & 10 \\
\hline Лейцин & 70 & 78 & 111,8 & 177 & 254,2 & 178 & 254,6 & 184 & 260,1 \\
\hline Лізин & 55 & 24 & 44,1 & 34 & 62,8 & 35 & 63,2 & 40 & 67,7 \\
\hline Метіонін & 35 & 16 & 45,7 & 40 & 115,0 & 40 & 115,1 & 46 & 120,3 \\
\hline Треонін & 40 & 30 & 75,5 & 34 & 85,7 & 35 & 86,1 & 39 & 91,1 \\
\hline Триптофан & 10 & 10 & 100,0 & 9 & 93,0 & 9 & 93,0 & 9 & 94,6 \\
\hline $\begin{array}{c}\text { Феніл- } \\
\text { аланін }\end{array}$ & 60 & 49 & 80,9 & 111 & 222,4 & 111 & 222,4 & 112 & 223,1 \\
\hline
\end{tabular}

Встановлено, що у макаронних виробах із кукурудзяного борошна міститься більше, ніж у 2 рази лейцину, фенілаланіну та метіоніну, порівнюючи 3 пшеничними виробами.

Лімітуючою амінокислотою для всіх зразків макаронни виробів $є$ лізин, проте АК скор за лізином білків кукурудзяних виробів є вищим приблизно у 1,5 раза, порівняно з пшеничними виробами. Для зразків з СЯБ це значення найвище і становить 67,7\%. Це свідчить про кращу засвоюваність білка кукурудзяних виробів.

За вмістом інших амінокислот кукурудзяні макаронні вироби мають також дещо вищі значення амінокислотного скору, крім амінокислоти триптофан.

На перетравлюваність макаронних виробів насамперед впливає їх хімічний склад, а також зміни структури при варінні продукту тощо. Результати досліджень перетравлюваності вуглеводів безглютенових макаронних виробів 3 кукурудзяного борошна зі структуроутворювачами ксантаном, КМЦ, желатином, СЯБ та виробів, виготовлених без їх застосування, порівняно з пшеничними макаронними виробами, наведені в табл. 4.

Таблиия 4. Результати досліджень перетравлюваності вуглеводів безглютенових макаронних виробів з кукурудзяного борошна

\begin{tabular}{|c|c|c|c|c|c|c|}
\hline \multirow{2}{*}{ Зразки макаронних виробів } & \multicolumn{5}{|c|}{ Тривалість гідролізу, хв } \\
\cline { 2 - 6 } & 0 & 45 & 90 & 135 & 180 \\
\cline { 2 - 6 } & \multicolumn{4}{|c|}{ вміст редукуючих речовин, \% на СР } \\
\hline $\begin{array}{c}\text { 3 пшеничного борошна вищого сорту } \\
\text { (контроль) }\end{array}$ & 0,20 & 0,44 & 0,58 & 1,41 & 1,59 \\
\hline $\begin{array}{c}\text { 3 кукурудзяного борошна : } \\
\text { з частиною завареного борошна (10\%) }\end{array}$ & 0,18 & 0,39 & 0,60 & 1,34 & 1,63 \\
\hline з екструдованим борошном (20\%) & 0,18 & 0,45 & 0,60 & 1,48 & 1,84 \\
\hline з ксантаном (0,7\%) & 0,36 & 0,48 & 0,60 & 1,57 & 1,82 \\
\hline 3 КМЦ (0,3\%) & 0,24 & 0,28 & 0,31 & 1,35 & 1,56 \\
\hline з желатином (1,0\%) & 0,21 & 0,31 & 0,33 & 1,41 & 1,55 \\
\hline з СЯБ (5,0\%) & 0,20 & 0,27 & 0,29 & 1,31 & 1,51 \\
\hline
\end{tabular}

3 отриманих даних (табл. 4) видно, що макаронні вироби з кукурудзяного i пшеничного борошна суттєво не відрізняються за перетравлюваністю вуглеводів. Перетравлюваність виробів за показником вмісту редукуючих речовин для зразка з частиною заваренного кукурудзяного борошна (10\%) практично відповідає значенням для пшеничних макаронних виробів (контролю). Для зразків з КМЦ, желатином та СЯБ ці значення близькі за тривалістю гідролізу — 
180 хв. Проте в процесі гідролізу вміст редукуючих речовин дещо нижчий, ніж у пшеничних виробах.

Безглютенові макаронні вироби з ксантаном та екструдованим кукурудзяним борошном гідролізуються краще, порівняно з іншими зразками, як 3 моменту початку гідролізу, так і після його закінчення, кількість редукуючих речовин на всіх етапах гідролізу є найбільшою. Імовірно, що гідроліз макаронних виробів з ксантаном проходить краще завдяки тому, що ксантан сам гідролізується у колоїдному розчині, оскільки він $є$ полісахаридом - галактомананом. Для зразка макаронних виробів 3 екструдованим кукурудзяним борошном це можна пояснити тим, що на всіх стадіях гідролізу в екструдованому борошні відбувається краща атакованість вуглеводів ферментами, завдяки розриву стінок клітин, руйнації структури гранул і розриву молекулярного ланцюга крохмалю при екструдуванні.

Результати дослідження перетравлюваності білків безглютенових макаронних виробів з виготовлених з використанням завареного борошна, желатину та СЯБ наведені на рис. 1 та в табл. 5.

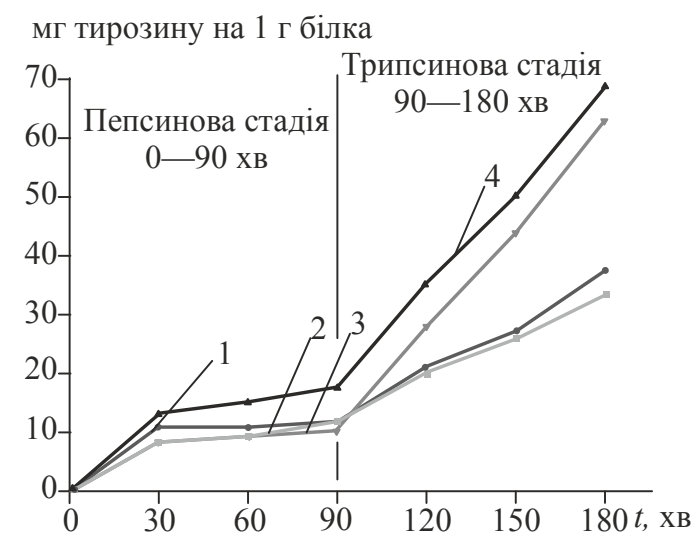

Рис. 1. Перетравлюваність білкових речовин макаронних виробів:

1 - пшеничні макаронні вироби; 2 - кукурудзяні з частиною завареного борошна; 3 - кукурудзяні $з$ желатином; 4 - кукурудзяні з СЯБ

Таблиия 5. Результати досліджень перетравлюваності білків безглютенових макаронних виробів 3 кукурудзяного борошна

\begin{tabular}{|c|c|c|c|c|}
\hline \multirow{6}{*}{$\begin{array}{c}\text { Тривалість, } \\
\text { хв }\end{array}$} & \multicolumn{4}{|c|}{ Макаронні вироби } \\
\hline & \multirow{4}{*}{$\begin{array}{c}3 \text { пшеничного } \\
\text { хлібопекарського } \\
\text { борошна вищого } \\
\text { сорту (контроль) }\end{array}$} & \multicolumn{3}{|c|}{ з кукурудзяного борошна } \\
\hline & & \multirow{3}{*}{\begin{tabular}{|c|} 
частиною $(10 \%)$ \\
завареного борошна \\
тонкого помелу \\
\end{tabular}} & з желатином & із СЯБ \\
\hline & & & \multicolumn{2}{|c|}{ у кількості, \% до маси борошна } \\
\hline & & & 1,0 & 5,0 \\
\hline & \multicolumn{4}{|c|}{ Перетравлюваність, мг тирозину на 1 г білка } \\
\hline 30 & 10,62 & 8,31 & 8,31 & 13,10 \\
\hline 60 & 10,71 & 9,42 & 9,25 & 15,21 \\
\hline 90 & 11,55 & 11,80 & 10,25 & 17,52 \\
\hline 120 & 21,12 & 20,01 & 28,11 & 35,26 \\
\hline 150 & 27,08 & 26,12 & 44,21 & 50,01 \\
\hline 180 & 37,41 & 33,43 & 62,89 & 68,89 \\
\hline
\end{tabular}


3 табл. 5. видно, що у разі збільшення кількості білка більше утворюється продуктів протеолізу. Білки кукурудзяних макаронних виробів із СяБ гідролізуються краще, вони утворюють в 1,5 раза більшу кількість продуктів протеолізу, ніж пшеничні та кукурудзяні вироби з частиною завареного борошна тонкого помелу.

Та сама залежність на збільшення кількості продуктів протеолізу прослідковується для макаронних виробів з СЯБ і під дією іншого протеолітичного ферменту — трипсину, на трипсиновій стадії гідролізу (90-180 хв).

Проте гідроліз відбувається інтенсивніше. Порівняно 3 пшеничними виробами вони утворюють в 1,8 раза більше продуктів протеолізу, а порівнюючи 3 кукурудзяними 3 частиною завареного борошна - в 2,1 раза. Це пов'язано 3 тим, що в процесі варіння СЯБ денатурує, а пептидні ланцюги міняють своє розташування в структурі, що сприяє більшій атакованості білків ферментами.

Білки безглютенових макаронних виробів із желатином гідролізуються на пепсиновій стадії дещо гірше порівняно 3 іншими зразками макаронних виробів, а кількість продуктів протеолізу найменша - 10,25 мг тирозину на 1 г білка. Хоч і на трипсиновій стадії вони гідролізують в 1,1 раза гірше, ніж вироби з СЯБ, але значно краще - в 1,7-1,9 раза, ніж пшеничні вироби та кукурудзяні з частиною завареного борошна відповідно.

Дані з перетравлюваності білків макаронних виробів з кукурудзяного борошна свідчать про кращу їх засвоюваність.

\section{Висновки}

1. Визначення харчової цінності безглютенових макаронних виробів з кукурудзяного борошна показало, що ці вироби збіднені на білок. Проте в них міститься більше вітамінів: особливо $\beta$-каротину, вітамінів групи $\mathrm{B}-\mathrm{B}_{1}, \mathrm{~B}_{2}$, PP і мінеральних речовин: заліза, кальцію, фосфору, магнію. Використання СЯБ у кількості 5,0\% сприяе збагаченню макаронних виробів білком, вміст якого сягає 10,94 мг на 100 г.

2. При споживанні 100 г макаронних виробів із СЯБ потреба у макро- i мікронутрієнтах забезпечується найбільше: в білках - на 16,33\%, в кальції на $4,43 \%$, у фосфорі - на 9,99\% та магнії - на $8,21 \%$.

3. Біологічна цінність безглютенових макаронних виробів $є$ вищою порівняно 3 пшеничними виробами, оскільки вони більш повноцінні за вмістом незамінних амінокислот, а саме: АК скор становить: за лізином - 62,8$67,7 \%$, лейцином - 254,2-260,1\%, фенілаланіном - 222,4-223,1\% та метіоніном - $115,0-120,3 \%$.

4. Перетравлюваність вуглеводів макаронних виробів 3 кукурудзяного i пшеничного борошна суттєво не відрізняється за кількістю редукуючих речовин. Зразки з ксантаном та 3 екструдованим кукурудзяним борошном, перетравлюються в 1,2 раза швидше порівняно з іншими зразками.

5. Перетравлюваність білкових речовин безглютенових макаронних виробів в 1,5 раза вища за кількістю продуктів пепсинового протеолізу та в 1,8 2,0 разів вища на трипсиновій стадії гідролізу порівняно 3 іншими зразками. Білки макаронних виробів 3 желатином гідролізуються дещо гірше, ніж зразки з СЯБ, проте краще, ніж пшеничні. Таким чином, перетравлюваність 
білкових речовин $є$ вищою для розроблених безглютенових макаронних виробів, що зумовлює їх кращу засвоюваність.

\section{Література}

1. Корячкина Р.Я. Функциональные пищевые ингредиенты и добавки для хлебобулочных и кондитерских изделий / Р.Я. Корячкина, Т.В. Матвеева // Санкт-Петербург : ГИОРД. 2013. - $528 \mathrm{c}$.

2. Шнейдер Д.В. Безбелковые и безглютеновые смеси для выпечки / Д.В. Шнейдер, Н.К. Казеннова // Хлебопечение России. — 2008. — № 1. — С. 23-24.

3. Gallagher E. Gluten-free Food Science and Technology / E. Gallagher // Wiley-Blackwell. - 2009. - P. 5-6.

4. Menrad K. Market and Marketing of Functional Food in Europe / K. Menrad // Journal of Food Engineering. - 2003. - Vol. 56. - \# 2-3. - P. 181-188.

5. Яхтанигова Ж.М. Химический состав и питательная ценность зерна и листостебельпой массы различных подвидов кукурузы / Ж.М. Яхтанигова // Новые технологии. - 2008. - Вып. 5. - С. 58-62.

6. Рожно O.В. Створення безглютенових макаронних виробів сприятиме забезпеченню населення України дієтичною продукцією / О.В. Рожно, В.Г. Юрчак // Хлебный и кондитерский бизнес. - Київ : ООО «Компания БИОПРОМ» - 2016. - № 10. - С. 27-28.

7. Rozhno $O$. The Influence of methods of making structurants on the quality of gluten-free pasta / O. Rozhno, O. Podobiy, V. Yurchak // 8th Central European Congress on Food 2016 Food Science for Well-being (CEFood 2016): Book of Abstracts. — 23-26 May 2016. Kyiv : NUFT. - 2016. - P. 143.

8. Rozhno O. Research of the Rheological Properties of Gelatine Solutions for Production of Gluten-Free Pasta / O. Rozhno, O. Podobiy, V. Yurchak // Ukrainian food journal. - Vol. 5. Issue 2. — Kyiv : NUFT. — 2016. — P. 290-298.

9. Патент 113395 UA, МПК A23L 7/109 (2016.01) Спосіб виготовлення макаронних виробів / Юрчак В. Г., Рожно О. В. - № u201607670 ; заявл. 12.07.2016 ; опубл. 25.01.2017, Бюл. № 2 .

10. Патент 113396 UA, МПК A23L 7/109 (2016. 01) Спосіб виготовлення макаронних виробів / Юрчак В.Г., Рожно О.В. — № u201607672 ; заявл. 12.07.2016 ; опубл. 25.01.2017, Бюл. № 2.

11. Технохімічний контроль сировини та хлібобулочних і макаронних виробів: навч. посіб. / за ред. В.І. Дробот // Київ : Кондор. — 2015. — 972 с.

12. Покровский A.A. Атакуемость белка пищевых продуктов протеолитическими ферментами in vitro / А.А. Покровский, И.Д. Ертанов // Вопросы питания. — 1965. — № 3. C. $38-44$. 